\title{
Aerobic Bacteria Pathogens Associated with Caprine Mastitis in Nsukka Area of Enugu State
}

\author{
${ }^{* 1}$ Ugochukwu, I. C. I., ${ }^{2}$ Anyaoha, C. O., ${ }^{1}$ Aneke, C. I., ${ }^{3}$ Idoko, S. I., ${ }^{4}$ Ugwu, J. U., ${ }^{5}$ Ughamba, K. T., \\ ${ }^{6}$ Edeh, E. R. and ${ }^{4}$ Ugochukwu, E. I. \\ ${ }^{1}$ Department of Veterinary Pathology and Microbiology, University of Nigeria, Nsukka \\ ${ }^{2}$ Department of Veterinary Public Health and Preventive Medicine, University of Nigeria, Nsukka. \\ ${ }^{3}$ Department of Veterinary Pathology, University of Abuja, Abuja. \\ ${ }^{4}$ Department of Veterinary Medicine, University of Nigeria, Nsukka. \\ ${ }^{5}$ Department of Microbiology, University of Nigeria, Nsukka. \\ ${ }^{6}$ Department of Veterinary Medicine, Ahmadu Bello University, Zaria.
}

*Corresponding Author:- iniobongugochukwu@unn.edu.ng; Tel.No +2348037322220

\begin{abstract}
This study ascertained the aerobic bacteria associated with cases of clinical and subclinical caprine mastitis. A total of 58 lactating West African dwarf does were used for this investigation. These lactating does had signs of clinical and sub-clinical mastitis. These samples were collected from Nsukka town, Nsukka abattoir, Orba Market, Obukpa Market and Obolllo - Afor market, all in Enugu State, Nigeria. Clinical mastitis was detected by gross signs of udder infection by physical examination of abnormal milk, whereas subclinical mastitis was recognized using California Mastitis test. This study showed that $39(67.24 \%)$ of 58 goats were positive for mastitis on California Mastitis Test. Clinical and subclinical cases of caprine mastitis, Staphylococcus aureus was the predominant pathogen $32(55.17 \%) .14(24.13 \%)$ of the isolates were positive for Staphylococcus epidermidis, 6 (10.34\%) for Streptoococcus agalactiae, 4 (6.89\%) E.coli and 2 (3.44\%) for Klebsiella pneumoniae. This work identified the bacterial species linked with caprine mastitis in Nsukka area of Enugu State.
\end{abstract}

Key words: Clinical mastitis, suclinical mastitis, aerobic bacteria, lactating, caprine.

\section{Introduction}

In Nigeria, one of the major limiting factors to the successful rearing of goats and sheep is disease, mastitis is a major one (Ugochukwu, 2008). The importance of goats as a source of meat and dairy products has been well discussed and documented by Haenlein (2004). Nigeria have an estimated goat population of 34.5 million (LawalAdebowale, 2012) but very little of this large population, is used for diary purposes (Ugochukwu, 1983b). For this reason, little attention has been directed to study the incidence and proffer control solution for caprine mastitis.

Mastitis, an inflammatory reaction of the udder tissue to bacterial, chemical, thermal or mechanical injury is characterised majorly by physical, chemical and bacteriological changes in milk with attending necrotic, pathological and glandular structural changes in defined areas of the udder (Togun et al., 2003). Mastitis is one of the major diseases in veterinary medicine. The global economic losses due to mastitis is about $\$ 35$ billion annually. In addition to the huge direct and indirect economic losses, the presence of certain pathogens in the milk is a major threat to public health (Bedolla and Castañeda, 2003; Bilal et al., 2004; Wolter et al. 2004; Ali et al., 2010). Mastitis is a complex disease with multiple predisposing factors and various causative agents (Harmon et al., 1990; Radostits et al., 2000; Tollersud et al., 2000; Bedolla, and Castañeda 2003; Bergioner et al., 2003). It is a disease complex which is dependent on several factors such as aetiologic agents, management practices such as the use of milking machine, susceptibility to the disease and efficiency of the host defence mechanisms (Ugochukwu, 1983b). Clinical mastitis may be easy to detect but animals suffering from subclinical mastitis are very difficult to diagnose since there is a lack of reliable 
diagnostic methods, especially at farm level (Leitner et al., 2004). Early diagnosis of subclinical mastitis is vital

Because changes in udder tissue take place much earlier than they become apparent (Contreras, 2007). However, the diagnosis of subclinical mastitis in goats is not easy but direct bacteriological assay could be used (Maisi and Riipinen, 1988; Maisi, 1990; Fthenakis, 1995; Gonzalez-Rodriguez and Carmenes, 1996; Sanchez et al., 2004).

Clinically, affected glands frequently suffer partial or complete damage and do not resume normal function (Fthenakis and Jones, 1990; Mørk et al., 2007). Most of the cases of mastitis studies show serious bacteria aetiological involvement. Many bacterial strains has been implicated in the aetiology of caprine mastitis, some frequently isolated organisms includes: Staphylococcus spp. Streptococcus. spp, E.coli, Corynebacterium spp. and Nocardia spp (Ugochukwu, 1983a; Ameh and Tari, 2000; Ajuwape et al ., 2005 Mørk et al.,2007). Some other bacterial species incriminated include Pseudomonas aeruginosa, Mannheimia haemolytica, Klebsiella spp, Pasteurella spp, Listeria monocytogenes and Fungi (Adetunji and Olaoye, 2012; Hawari et al., 2014). Control measures for mastitis are important in order to reduce economic losses and decrease the risk of diseases, being transmitted to humans via food (Cortimiglia et al., 2015).

There has been little knowledge of the aetiology of this disease. Goat and sheep industries is gaining grounds in some part of Nigeria, coupled with the dearth of information in available scientific literature on caprine mastitis in Nsukka area and the Southeastern part of Nigeria, necessitated this bacteriological investigation.

\section{Materials and Methods}

\section{Study area}

The study areas are Nsukka and Obukpa market in Nsukka Local Government Area, Orba and Obollo Afor market in Udenu Local Government Area, Enugu State, Nigeria. Nsukka is situated at latitude $6^{\circ} 51^{\prime} 24^{\prime \prime} \mathrm{N}$ and longitude $7^{\circ} 23^{\prime} 45^{\prime \prime} \mathrm{E}$, with a total Landmass of 17.52 sq. miles $\left(45.38 \mathrm{~km}^{2}\right)$, an annual mean humidity of $13 \%$ and an elevation of $1,810 \mathrm{ft}(550 \mathrm{~m})$ above sea level. The geographical coordinates for Orba is $6^{\circ} 51^{\prime} 0^{\prime \prime} \mathrm{N}$, $7^{\circ} 27^{\prime} 0^{\prime \prime} \mathrm{E}$, while Obollo is located at $6^{\circ} 55^{\prime} \mathrm{N} 7^{\circ} 31^{\prime} \mathrm{E}$.

\section{Study animals}

Animals used for this investigation were 58 lactating West African dwarf does with obvious clinical signs of clinical and sub-clinical mastitis.

\section{Sample collection}

Samples were collected from clinical and subclinical cases of mastitis. The milk samples were collected under complete aseptic conditions.

\section{Diagnosis of Clinical and sub-clinical mastitis}

Clinical mastitis was detected by gross signs of udder infection during physical examination of abnormal milk, while subclinical mastitis was recognized using California Mastitis test (CMT) following standard procedures described by Assefa, et al ., (2006). Milk samples of the goats with clinical and subclinical mastitis were subjected for isolation and identification of bacterial pathogens.

\section{Isolation and identification of bacterial agents}

Samples were kept in the refrigerator at $4^{\circ} \mathrm{C}$ within a maximum of $12 \mathrm{~h}$ after sampling before examination. The samples were centrifuged at $1500 \mathrm{rpm}$ for $30 \mathrm{~min}$ as recommended by Yousof Beighi et al. (2005). The sediments were cultured in Blood agar, MacConkey agar and Nutrient agar plates. The inoculated plates were incubated under aerobe conditions at $37^{\circ} \mathrm{C}$ and colonial growth was checked after $24 \mathrm{~h}$. The colonial morphology and type of haemolysis were recorded. After Gram staining, the suspected pure colonies of gram positive were also identified by culturing in Mannitol salt agar, Catalase Test and Tube Coagulase Test using standard procedures as described by Chessbrough (2000). The Gram negative rods were subjected to Giemsa staining, indole, sugar utilization and urease tests as well as reaction on eosin methylene blue agar and Triple sugar iron agar (TSI agar) according to standard procedures described by Chessbrough (2000). Identification of the bacterial agents from the pure culture were based on colony characteristics, gram staining reaction, hemolysis pattern and biochemical test described by Chessbrough (2000). 


\section{Results and Discussion}

\section{Bacteriological findings}

The distribution of aerobic bacteria isolated from secretions from the glands with clinical and subclinical mastitis is shown in Figure 1. Staphylococcus aureus was the predominant pathogen and was $32(55.17 \%)$ of the samples from the mastitic glands. $14(24.13 \%)$ of the isolates were Staphylococcus epidermidis, 6 $(10.34 \%)$ of the isolates were Streptoococcus agalactiae, $4(6.89 \%)$ of the isolates were positive for $E$. coli and $2(3.44 \%)$ of the isolates were positive for Klebsiella pneumoniae as shown in Figure 2. Table 1 shows biochemical tests and physiological test: Catalase, Tube coagulase, oxidase, indole, urease tests and sugar utilization tests.

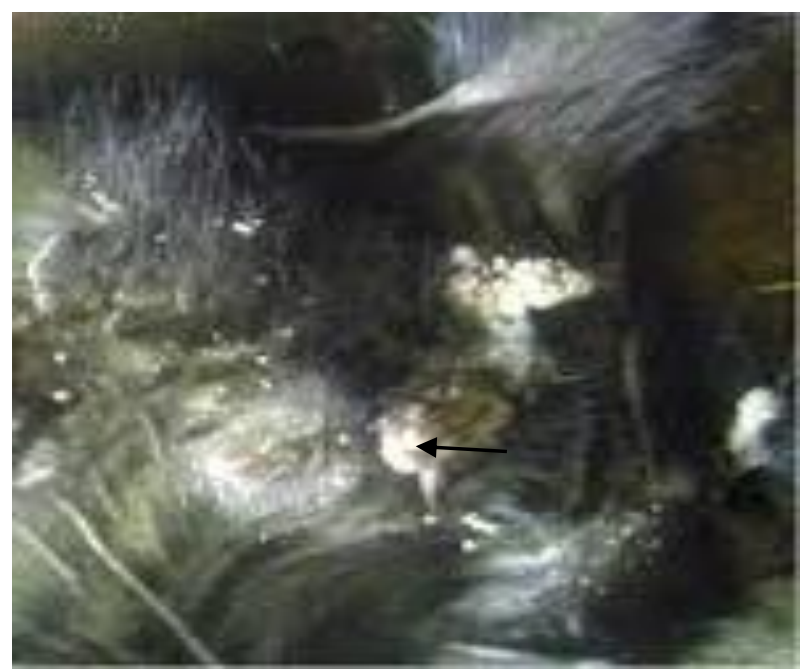

Figure 1: Mastitic teat of West African dwarf Doe arrows showing the inflammed teat

\section{California Mastitis test results}

In this test, out of 58 lactating does, 39 (67.24\%) were positive for mastitis on California Mastitis
Test (CMT), this is shown in Table 2. $28(71.79 \%)$ of the West African Dwarf goats were positive for mastitis on CMT, while $11(28.20 \%)$ of the Kano Brown goats were positive for mastitis on CMT. A mastitic teat from the two examined breeds observed with mastitis is shown in Figures 2 and 3.

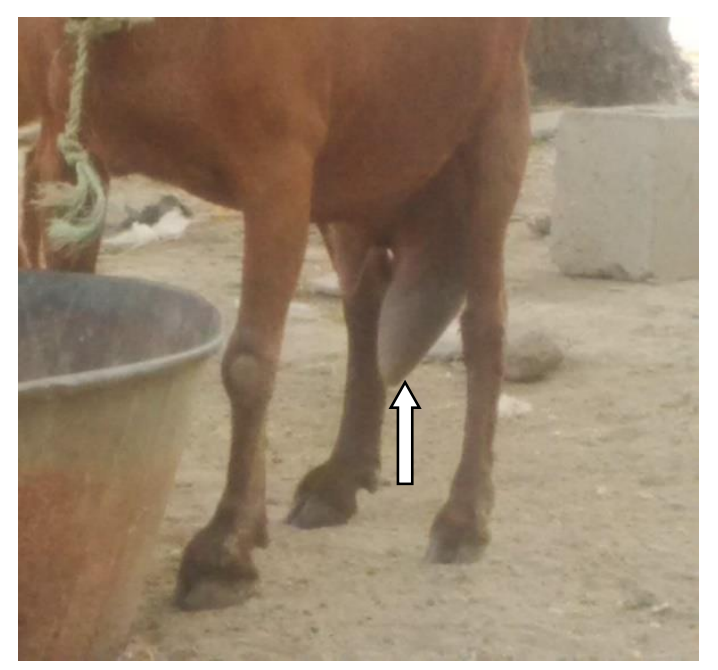

\section{Bacteriological findings}

The distribution of aerobic bacteria isolated from secretions from the glands with clinical and subclinical mastitis is shown in Figure 3. Staphylococcus aureus was the predominant pathogen and was $32(55.17 \%)$ of the samples from the mastitic glands. $14(24.13 \%)$ of the isolates were Staphylococcus epidermidis, 6 $(10.34 \%)$ of the isolates were Streptoococcus agalactiae, $4(6.89 \%)$ of the isolates were positive for $E$. coli and $2(3.44 \%)$ of the isolates were positive for Klebsiella pneumoniae as shown in Figure 2. Table 1 shows biochemical tests and physiological test: Catalase, Tube coagulase, oxidase, indole, urease tests and sugar utilization tests. 
Table 1: Physiological tests and biochemical tests results for the aerobic bacteria isolated from secretions from the glands of lactating does with clinical and subclinical mastitis in Nsukka area

Aerobic bacteria isolate $S$. aureus S. epidermidis S. agalactiae $\quad$ E. coli $\quad$ K. pneumoniae

Tests

\begin{tabular}{|c|c|c|c|c|c|}
\hline Gram & $+\mathrm{ve}$ & +ve & $+\mathrm{ve}$ & -ve & -ve \\
\hline Catalase & $+\mathrm{ve}$ & $+\mathrm{ve}$ & -ve & $+\mathrm{ve}$ & $+\mathrm{ve}$ \\
\hline Coagulase & $+/$-ve & -ve & -ve & ND & ND \\
\hline Oxidase & -ve & -ve & -ve & -ve & -ve \\
\hline Indole & -ve & -ve & -ve & $+\mathrm{ve}$ & -ve \\
\hline Urease & +ve & +ve & -ve & -ve & $+\mathrm{ve}$ \\
\hline Motility & -ve & -ve & -ve & $+v e$ & -ve \\
\hline D-glucose & $+\mathrm{ve}$ & $+\mathrm{ve}$ & $+v e$ & $+\mathrm{ve}$ & $+\mathrm{ve}$ \\
\hline Sucrose & + ve & + ve & $+\mathrm{ve}$ & + ve & + ve \\
\hline Lactose & + ve & $+\mathrm{ve}$ & -ve & $+\mathrm{ve}$ & $+\mathrm{ve}$ \\
\hline Maltose & $+\mathrm{ve}$ & $+\mathrm{ve}$ & +ve & + ve & $+\mathrm{ve}$ \\
\hline D-mannitol & $+v e$ & -ve & -ve & $+\mathrm{ve}$ & $+\mathrm{ve}$ \\
\hline \multicolumn{6}{|c|}{ Triple Sugar Iron Agar } \\
\hline $\mathrm{H}_{2} \mathrm{~S}$ production & -ve & $+\mathrm{ve}$ & -ve & -ve & +ve \\
\hline Gas production & -ve & +ve & -ve & $+\mathrm{ve}$ & $+\mathrm{ve}$ \\
\hline
\end{tabular}

*ND - Not done

Table 2: Breed distribution of lactating does with clinical and subclinical mastitis in Nsukka area

\begin{tabular}{lcc}
\hline $\begin{array}{l}\text { Breed } \\
+\mathrm{ve}\end{array}$ & Number of affected lactating Does & Number CMT \\
\hline West African Dwarf & 41 & 28 \\
Kano brown & 17 & 11 \\
Total & 58 & 39 \\
\hline
\end{tabular}

Caprine mastitis is caused by bacteria of primary or secondary involvements. The udder could also be exposed to trauma from hard objects like broken bottles and rusty metals in their scavenging environment, which make the goats susceptible to mastitis - causing organisms 
(Togun et al., 2003). Raw goat's milk can be a potential source of antibiotic resistant pathogens on animal, human, and environment. Microorganisms which contaminate raw milk may originate from the farm environment or goats which include aetiological agents responsible for clinical and subclinical mastitis (Virdis et al., 2010).

In this study the bacterial isolates include Staphylococcus aureus, Staphylococcus epidermidis, Streptoococcus agalactiae, E. coli and Klebsiella pneumoniae this agrees with the reports of Ugochukwu, (1983a); Ndegwa et al., (2001); Sousa et al., (2007); Ali et al. (2010); Islam et al. (2011); Hawari et al. (2014).

Out of the 58 isolates, Staphylococcus aureus had the highest isolation occurrence of 32 $(55.17 \%) . \quad 9 \quad(28.12 \%)$ out of the 32 Staphylococcus aureus isolates were Coagulase negative Staphylococcus aureus. Coagulasenegative staphylococci isolated in this study, although not a major pathogen of clinical mastitis in goats, has been shown to persist throughout the lactation and dry periods, irritating the gland and causing a decrease in production and even clinical mastitis (Ndegwa et al., 2001).

Staphylococcus aureus has been incriminated in much suppurative conditions in man and animals (Greenwood et al., 2002; Kitara et al., 2011). Coagulase positive Staphylococcus aureus is known to be involved in mastitis in most species of domestic animals including goats, pigs, cattle and sheep (Radostits et al., 2000). It has also been isolated with the highest frequency in other works as reported by Mørk et al., (2007), Ali et al., (2010) and Islam et al., (2011). The occurrence of a high number of coagulase positive Staphylococcus aureus suggest its involvement in the causation of caprine mastitis. Staphylococcus epidermidis isolated in this study is widely known to be harmless and the precise role of these bacteria in the pathogenesis of mastitis is not understood but has been associated with subclinical mastitis. It has been isolated by Contreras et al., (2003) and Razi et al., (2012).
Escherichia coli is a normal microflora of the gut. It is usually present in the faecal materials. Contamination of the udder by faecal materials could have led to the presence of the organism in the milk. Isolation of $E$. coli in this study agrees with the findings of Islam et al., (2011), Hawari et al., (2014) and Mbindyo et al. (2014).

Streptococcus agalactiae, a notorious agent for mastitis (Kateeke et al., 2013). Castañeda et al., (2013) and Hawari et al. (2014), reported isolation and identification of this organism from clinical cases of mastitis in their works on mastititis in caprines, bovines and ovines, in Northern Nigeria, Mexico and Al-Balqa province in Jordan, respectively.

Bacteria such as Streptococcus dysgalactiae, Corynebacterium spp., Mannheimia haemolytica, Pasteurella multocida, Arcanobacterium pyogenes, Clostridium perfringens which have been associated with chronic mastitis, that have been isolated by Mørk et al., (2007), Ibrahim et al., (2009), Ahmadi et al., (2014) and Hawari et al., (2014).

The differences in the Breed distribution of Mastitis, in which there was more cases in WAD goats compared to Kano Brown goat is due to the fact that WAD goats are the predominantly reared goat breed in Southeastern Nigeria.

In the present circumstances, goats and sheep industry is gaining considerable attention since 1983 as reported by Ugochukwu, 1983b. It is important as part of control measures to encourage indigenous farmers to report cases of mastitis to the nearest veterinary clinics.

In conclusion, this work identified the bacterial species involved in caprine mastitis in Nsukka area of Enugu State. It is believed that this investigation will stimulate research on other pathogens associated with caprine mastitis

\section{Acknowledgements}

The authors' special appreciation to the staff of Veterinary Microbiology Laboratory of the Faculty 
of Veterinary Medicine, University of Nigeria, Nsukka for their technical assistance.

\section{Conflict of Interest}

There is no conflict of interest regarding the manuscript.

\section{References}

Adetunji, V. O. and Olaoye, O. O (2012). Incidence and antibiotic susceptibility pattern of Listeria monocytogenes isolates from milk of West African Dwarf and Red Sokoto breeds of goat from Southwestern Nigeria. New York Sci J. 5 (11): 68-73.

Ahmadi, N., Yazdi, H.S., Derakhshandeh, A. and Ghane M. (2014). Acute Mastitis Caused by Pasteurella multocida in a goat: Clinicopathological and Microbiological Findings. Braz J Vet. Pathol; 7 (1): 25 - 28.

Ajuwape, A.T.P., Roberts, A.A., Solarin, A.A. and Adetosoye, A.I. (2005). Bacteriological and haematological studies of clinical mastitis in goats in Ibadan, Oyo State, Nigeria. Small. Rum. Res. 60: 307-310.

Ali, Z., Muhammad, G., Ahmad T, Khan, R., Naz, S., Hasib-Anwar, H., Farooq A. F., Manzoor, M.N. and Usama, AR. (2010). Prevalence of Caprine Sub-Clinical Mastitis, its Etiological Agents and their Sensitivity to Antibiotics in Indigenous Breeds of Kohat, Pakistan. Pak life Soc Sci. 8 (1): 63-67.

Ameh, J.A. and Tari, I.S. (2000). Observation on the prevalence of caprine mastitis in relation to predisposing factors in Maiduguri. Small Rum Res 35(1): 1-5

Assefa, W., Molla, B., Belihu, K.and Kleer, J. and Hildebrandt, G. (2006). A cross-sectional study on the prevalence, antimicrobial susceptibility patterns, and associated bacterial pathogens of goat mastitis. Int J Appl Res Vet Med 4: 169-176.

Bedolla, C.C. and Castañeda, V.H. (2003). Agentes patógenos causantes de la mastitis bovina. Cuatro vientos. 38: 27-29.

Bergdoll, M.S. (1989). Staphylococcus aureus. In: Doyle, M.P. (Ed) Foodborne bacterial pathogens.. New York and Basel: Marcel Dekker; Pp 463-473.

Bergonier, D., De Crémoux R., Rupp R., Lagriffoul G., Berthelot, X. (2003). Mastitis of dairy small ruminants. Vet. Res. 34: 689-716.

Bilal, M., Iqbal, M., Muhammad, G.and Avais, M. (2004).Factors Affecting the Prevalence of Clinical Mastitis in Buffaloes around Faisalabad District (Pakistan). Int J Agri Biol 6: 185-187.

Castañeda V.H, Jäger S, Wolter W, Zschöck M, Castañeda V.M.A. and El-Sayed A. (2013) Isolation and identification of main mastitis pathogens in Mexico. Arq Bras Med Vet Zootec 65(2): 377-382.

Chessbrough, M. (2000). District Laboratory Practice in Tropical Countries Part 2. Low Price Edn. Cambridge UK. p. 39-70, 395.

Contreras, A.C., Sánchez, L.A. and Corrales, J.C. (2003). The role of intramammary pathogens in dairy goats. Livest Prod Sci. 79:273-83.

Contreras, A., D., Sierra, A., Sanchez, J.C., Corrales, J.C., Marcoc, M.J. Paape and Gonzalo, C. (2007).Mastitis in small ruminants. Small Rum. Res., 68:145-153.

Cortimiglia, C., Bianchini, V., Franco, A, Caprioli A, Battisti A, Colombo, L., Stradiotto, K., Vezzoli, F. and Luini, M. (2015) Short communication: Prevalence of Staphylococcus aureus and methicillinresistant $\mathrm{S}$. aureus (MRSA) in bulk tank milk of dairy goat farms from Northern Italy. $J$ Dairy Sci 98: 2307-2311.

Fthenakis, G.C. and Jones, J. E. T. (1990). The effect of experimentally induced subclinical mastitis on milk yield of ewes and on the growth of lambs. Br Vet J. 14:43-49.

Fthenakis, G.C. (1995). Californa mastitis test and Whiteside test in diagnosis of subclinical masttis of diary ewes. Small Rum Res. 13: 293-300.

Gonzales- Rodriguez, M.C and Carmanes P. (1996). Evaluation of the California mastitis test as a discriminant method to detect subclinical mastitis in dairy cows. Int $J$ Antimicrob Agents; 19:219-226. 
Greenwood, D., Slack R.C.B and Peutherer, J.F. (2002). Medical Microbiology. 16th Edn., Churchill Livingstone, Edinburgh-London-New York-Philadelphia-St. Louis-Sydney-Toronto, pp: 168-173.

Haenlein, G.F.W. (2004). Goats milk in human nutrition. Small Rum Res, 51: 155-163.

Harmon, R.J., Eberhardt, R.J. and Jasper, D.E. (1990). Microbiological procedures for the diagnosis of bovine udder infection, 3rd edition. Arlington, VA: National Mastitis Council; p. 34.

Hawari, A.D., Obeidat, M., Saddam, S.H. Awaisheh, S.S., Al-Daghistani, H.I., AlAbbadi, A.A., Omar, S.S., Qrunfleh, I.M. et al. (2014). Prevalence of Mastitis pathogens and their resistance against antimicrobial agents in Awassi sheep in Al-Balqa Province of Jordan. Amer J Anim Vet Sci; 9 (2): 116-121.

Ibrahim, A., Kursat ,K., Haci, A.C. (2009). Identification and antimicrobial subseptibilty of sub-clinical mastitis pathogens isolated from hair goat's milk. J Anim Vet Adv 8 (6): 10861090.

Islam, M.A., Samad, M.A.and Anisur-Rahman, A.K.M. (2011). Bacterial pathogens and Risk Factors associated with Mastitis in Black Bengal goats in Bangladesh. Bangl $J$ Vet Med 9 (2): 155 - 159.

Kateete, D.P., Kabugo, U., Baluku, H., Nyakarahuka, L., Kyobe, S., Okee, M., Najjuka, C.F.and Joloba M.L. (2013). Prevalence and antimicrobial susceptibility patterns of bacteria from milkmen and cows with clinical mastitis in and around Kampala, Uganda. PLoS ONE, 8(5): e63413.

Kitara, L.D., AD Anywar, A.D., Acullu, D., OdongoAginya, E., Aloyo, J and Fendu, M. (2011). Antibiotic susceptibility of Staphylococcus aureus in suppurative lesions in Lacor Hospital, Uganda. Afr Health Sci 11(1): S34S39.

Lawal-Adebowale OA. (2012) Dynamics of Ruminant Livestock Management in the Context of the Nigerian Agricultural System. In: Javed K. (editor) Livestock Production. pp. 60-63.
Leitner, G., Merin, U., Silanikove, N., Ezra, E., Chaffer, M., Gollop, N., Winkler, M., Glickman, A. and Saran, A. (2004). Effect of subclinical intramammary infection on somatic cell counts, NAGase activity and gross composition of goats' milk. J Dairy Res 71(3): 311-315.

Maisi, P. and Riipinnen I. (1988). Use of California mastitis test, $\mathrm{N}$-acetyl-glucosamidase and antitrypsin to diagnose caprine subclinical mastitis. J Dairy Res 55: 309-314.

Maisi, P. (1990). Analysis of physiological changes in caprine milk with CMT, NA Gase and antitrypsin. Small Rum Res; 3: 485-492.

Mbindyo, C.M., Gitao, C.G.and Bebora, L. (2014). A cross-sectional study on the prevalence of subclinical mastitis and antimicrobial susceptibility patterns of the bacterial isolates in milk samples of smallholder dairy goats in Kenya. Amer J Res Commun. 2(8): 30-51.

Mørk, T., Waage, S., Tollersrud, T., Kvitle, B. and Sviland, S., (2007). Clinical mastitis in ewes; bacteriology, epidemiology and clinical features. Acta Vet Scand 49: (23): 1-8.

Ndegwa, E.N., Mulei, C.M. and Munyua, S.J.M. (2001). Prevalence of microorganisms associated with udder infections in dairy goats on small-scale farms in Kenya. $J S$ Afr Vet Ass, 72 (2): 97-98.

Radostitis, O. M., Gay, C. C., Blood, D. C. and Hinchcliff, K. W. (2000). Mastitis. In Veterinary Medicine 9th ed., W. B. Saunders, London. pp. 601-700.

Razi, K.M.A, Rahman, M.B., Flores-Gutiérrez, G.H. and Rahman, M.T. (2012). Prevalence of caprine subclinical mastitis in Mymensingh area and characterization of associated bacterial agents and the risk factors. Microb HIth 1 (1): 1-5.

Sanchez, A., Contreras, A., Corrales, J.C. and Munoz, P. (2004). Influence of sampling time on bacteriological diagnosis of goat intramammary infection. Vet Microbiol 98: 329-332.

Sousa, M.A., Parente, C.E.S.R., Motta, O.V., Bonna, I.C.F., Silva, D.A. and Lencastre, H 
(2007). Characterization of Staphylococcus aureus isolates from buffalo, bovine, ovine, and caprine milk samples collected in Rio de Janeiro State, Brazil. Appl Envir Microbiol 73 (12): 3845-3849.

Togun, V.A., Amao, O.A., Oyebode, O.A. and Ajibade, E.A. (2003). Occurrence of Mastitis cases in West African dwarf goats under extensive system of management in Ogbomoso. Asset Series A. 3 (4):121-125.

Tollersrud, T., Kenny, K., Caugant, D. A. and Lund, A. (2000). Characterisation of isolates of Staphylococcus aureus from acute, chronic and subclinical mastitis in cows in Norway. APMIS 108: 565-572.

Ugochukwu, E.I. (1983a). Staphylococccal mastitis in West African dwarf goats. A case report. Nig Vet J. 12 (19): 9-12.

Ugochukwu, E.I., (1983b). Isolation, identification and antibiotic sensitivity of Staphylococcus spp from goats suffering from mastitis in
Anambra State of Nigeria. Bull Anim HIth Prod Africa 1983b; 31(4): 349-352.

Ugochukwu, E.I. (2008). Isolation and characterization of Pasteurella multocida from caprine pneumonic lungs. Anim Res Int 5 (2): 880-882.

Virdis, S., Scarano, C., Cossu, F., Spanu, V., Spanu, C.and De Santis, E.P.L. (2010). Antibiotic resistance in Staphylococcus aureus and Coagulase Negative Staphylococci isolated from goats with subclinical mastitis. Vet Med Int. Article ID 517060 .

Wolter, W., Castaneda, H., Klopert, B. and Zchöck, M. (2004). Mastitis Bovina, Prevención, Diagnostico y Tratamiento. 1. Ed. Editorial Universitaria: Universidad de Guadalajara. Guadalajara Jalisco. p.1-146.

Yousof-Beighi, G.H., Rad, M., Hosseini, S.M. and Jafari A. (2005). Effect of centrifugation of milk samples on bacteriologic culture. Iranian $J$ Vet Res 6: 59-61. 